\title{
PREDIKSI PERTUMBUHAN PERBANKAN SYARIAH DI INDONESIA TAHUN 2020 DENGAN QUANTITATIVE METHODS
}

\author{
Aam Slamet Rusydiana \\ Islamic Economics Department, Tazkia University and researcher at SMART Indonesia. Email: \\ aamsmart@gmail.com.
}

\begin{abstract}
This study aims to predict the growth of Islamic banks assets in Indonesia for the year 2020. There are three schemes of forecasting count: pessimistic, moderate and optimistic. The results show that with the Multiplicative Decomposition method, the assets of Indonesian Islamic banks are estimated to reach $R p 523.72$ trillion at the end of 2020. Slightly different from those results, with the trend analysis method, the assets of Indonesian Islamic banks are estimated at Rp 516.09 trillion. As for using the exponential smoothing approach with a trend at the end of 2020 the assets of Indonesian Islamic banks are estimated to reach Rp. 553 trillion. So, if nothing extraordinary happens - which is inorganic - and the assumption of 'ceteris paribus', the assets of Islamic banks in Indonesia at the end of 2020 will be in the range of Rp. 516 to Rp. 553 trillion 'only'. The growth of Indonesian Islamic banks asset in 2020 is between 7.3\%-14.9\%. This is expected to be realized.
\end{abstract}

Keywords: Indonesian Islamic Banks, Forecasting, 2020, Quantitative Methods

\begin{abstract}
ABSTRAK
Penelitian ini bertujuan untuk memprediksi pertumbuhan aset bank syariah di Indonesia untuk tahun 2020. Ada tiga skema perhitungan perkiraan: pesimistis, moderat, dan optimis. Hasil penelitian menunjukkan bahwa dengan metode Multiplicative Decomposition, aset bank syariah Indonesia diperkirakan mencapai Rp 523,72 triliun pada akhir tahun 2020. Sedikit berbeda dari hasil tersebut, dengan metode analisis tren, aset bank syariah Indonesia diperkirakan mencapai Rp 516,09 triliun. Sedangkan dengan menggunakan pendekatan Exponential Smoothing dengan tren pada akhir 2020, aset bank syariah Indonesia diperkirakan mencapai Rp. 553 triliun. Jadi, jika tidak ada hal yang luar biasa terjadi - yang anorganik - dan asumsi 'ceteris paribus', aset bank syariah di Indonesia pada akhir 2020 'hanya' akan berada pada kisaran Rp. 516 hingga Rp. 553 triliun. Pertumbuhan aset bank syariah Indonesia pada tahun 2020 adalah antara 7,3\%-14,9\%. Angka ini diharapkan dapat terwujud.
\end{abstract}

Kata Kunci: Bank Syariah Indonesia, Prediksi, 2020, Quantitative Methods 


\section{PENDAHULUAN}

Indonesia merupakan salah satu negara yang menerapkan sistem keuangan ganda yaitu sistem keuangan konvensional dan sistem keuangan Islam (syariah). Keuangan syariah di Indonesia baru muncul sekitar tahun 1992 yang dipelopori oleh Bank Muamalat Indonesia. Setelah itu mulai berkembang Bank Umum Syariah, Unit Usaha Syariah, Bank Pembiayaan Rakyat Syariah (BPRS), Koperasi Syariah, Asuransi Syariah, Pegadaian Syariah, Wakaf, dan Lembaga Keuangan Syariah (LKS) lainnya. Secara bersama-sama, sistem keuangan syariah dan keuangan konvensional secara sinergis mendukung mobilisasi dana masyarakat secara lebih luas untuk meningkatkan kemampuan pembiayaan bagi sektor-sektor perekonomian nasional. Menurut Nurfalah et.al (Nurfalah, Rusydiana, Laila, \& Cahyono, 2018), perbankan syariah relatif lebih stabil dibandingkan dengan perbankan konvensional dalam menghadapi shock baik dari internal maupun eksternal. Hal ini menjadi temuan menarik yang perlu dibuktikan melalui berbagai riset di masa mendatang.

Permintaan atas pembiayaan syariah mengalami tren peningkatan yang cukup tajam dari tahun ke tahun. Permintaan atas pembiayaan syariah tidak hanya dilakukan oleh umat Muslim melainkan juga non-muslim. Seperti juga halnya dengan Lembaga Keuangan Syariah yang menangani pembiayaan seperti, Bank Syariah, Bank Perkreditan Rakyat Syariah (BPRS), Baitul Mal wat Tamwil (BMT), Koperasi Jasa Keuangan Syariah (KJKS) dan lainnya menunjukkan angka pertumbuhan yang tinggi. Saat ini, keberadaannya dibutuhkan oleh masyarakat terutama bagi para pelaku usaha mikro karena dapat menjangkau masyarakat lapisan menengah bawah (Adawiyah \& Subaweh, 2013).

Perekonomian Indonesia dapat dikatakan memiliki fundamental yang kuat, jika ekonomi rakyat telah menjadi pelaku utama yang produktif dan berdaya saing dalam perekonomian nasional. Maka dari itu, pembangunan ekonomi rakyat melalui pemberdayaan usaha mikro menjadi prioritas utama pembangunan ekonomi nasional dalam jangka panjang (Deperindag, 2002).

Pertumbuhan industri keuangan syariah di Indonesia dipengaruhi oleh permintaan masyarakat terhadap penggunaan transaksi berbasis syariah yang meningkat signifikan. Adapun berbagai macam produk syariah yang digunakan masyarakat seperti pembiayaan, pembelian suatu barang, investasi, sukuk, dan produk lainnya.

Prospek ekonomi syariah semakin menjanjikan, seiring dengan eksistensi Dewan Syariah Nasional (DSN) yang meningkat. Lembaga pendidikan ekonomi syariah juga meningkat. Efek globalisasi juga menunjukkan keunggulan ekonomi Islam makin dikenal secara internasional. Terbukti semakin banyak lembaga keuangan internasional, baik bank maupun pasar modal, yang membuka unit syariah. Bahkan Inggris baru-baru ini meresmikan bank Islam. Singapura pun sangat berambisi untuk mengembangkan ekonomi syariah (Latianingsih \& Ninggarwati, 2010).

Fungsi dan peran ekonomi serta keuangan syariah dalam sistem keuangan saat ini lebih diharapkan, terlebih pengalaman krisis keuangan telah menyadarkan kembali akan esensi aktivitas lembaga keuangan. Ekonomi dan keuangan syariah, secara konsep telah berbasis 
kepada transaksi riil yang tidak melakukan praktek spekulasi dan tidak mengabaikan fundamental ekonomi dan keuangan yang sebenarnya, sehingga tidak menimbulkan adanya bubble dalam ekonomi dan sistem keuangan.

Sistem ekonomi dan keuangan syariah hadir berlandaskan kepada pencapaian keadilan dan distribusi kesejahteraan ekonomi maupun ethical value yang bersifat universal, yang dapat diterima oleh berbagai pihak. Dalam tataran praktis, pada akhirnya ekonomi dan keuangan syariah memberikan garis keterkaitan yang jelas bahwa produk dan transaksi keuangan yang terjadi dalam pasar harus memiliki keterkaitan erat dan berhubungan langsung dengan sektor riil (OJK: 2013).

Infrastruktur keuangan Islam kontemporer berkembang mengikuti infrastruktur keuangan konvensional yang secara garis besar meliputi (Ascarya: 2007) beberapa lembaga keuangan dan sosial Islam. Salah satu yang utama adalah industri perbankan syariah. Bank Syariah; adalah bank yang melaksanakan kegiatan usaha berdasarkan prinsip Syariah, yaitu aturan perjanjian berdasarkan hukum Islam antara bank dan pihak lain untuk penyimpanan dana dan atau pembiayaan kegiatan usaha, atau kegiatan lainnya yang dinyatakan sesuai dengan Syariah (nilai-nilai makro dan mikro). Bank syariah dapat berbentuk bank umum (full-fledged), unit syariah (full branch), bank perkreditan rakyat (rural bank), dan produk syariah di bank konvensional (windows).

Perkembangan lembaga keuangan syariah di Indonesia dapat terefleksikan dari jumlah total Aset, DPK, dan pembiayaannya. Ketiga indikator tersebut merupakan pokok perkembangan lembaga keuangan syariah (Yuliani \& Kuswanto, 2010). Dalam perbankan, total aset dipengaruhi oleh tinggi rendahnya jumlah DPK dan pembiayaan. Sebagaimana penelitian Pratiwhi (Pratiwhi, 2008) dan Ulfah (Ulfah, M, 2009) yang membuktikan bahwa DPK dan pembiayaan merupakan dua faktor yang mempengaruhi aset secara signifikan yang berarti bahwa pengoptimalan aset dapat dilakukan melalui peningkatan penghimpunan DPK dan mempromosikan pembiayaan kepada masyarakat. Berdasarkan data Otoritas Jasa Keuangan (OJK) Republik Indonesia pada tahun 2015, total aset perbankan syariah menunjukkan tren positif yaitu sebesar 296 triliun yang meningkat, dibandingkan dengan tahun sebelumnya yaitu sebesar 272 triliun pada tahun 2014.

Beberapa riset terkait perbankan syariah di Indonesia terutama berkaitan dengan pengukuran performa bank syariah telah banyak dilakukan studi terdahulu. Misalnya penelitian yang dilakukan oleh Rani et.al (Rani, Rusydiana, \& Widiastuti, t.t.). Demikian juga Rusydiana (Rusydiana, 2018), (Rusydiana \& Sanrego, 2018), dan (Rusydiana \& Firmansyah, 2017).

Dari latar belakang tersebut dapat diketahui bahwa, total aset merupakan salah satu refleksi perkembangan lembaga keuangan syariah. Semakin besar market share yang dimiliki oleh lembaga keuangan syariah, semakin besar pula total aset yang dapat dicapai. Maka dari itu, dalam penelitian ini penulis mencoba melakukan prediksi seberapa besar total aset yang akan dicapai khususnya pada lembaga perbankan syariah di Indonesia pada akhir tahun 2018. Dengan adanya penelitian ini, diharapkan dapat memberikan gambaran umum prediksi pencapaian total aset perbankan syariah. 


\section{LITERATUR REVIEW}

\section{Konsep Aset}

Aset adalah kekayaan atau harta yang dimiliki perusahaan, yang berperan dalam operasi perusahaan misalnya kas, persediaan, aktiva tetap, aktiva tak berwujud, dan lain- lain (Lubis, 2008). Berdasarkan pernyataan FASB (1985), aset adalah kemungkinan keuntungan ekonomi yang diperoleh atau dikuasai dimasa yang akan datang oleh lembaga tertentu sebagai akibat transaksi atau kejadian yang telah berlaku. Total aset selain menunjukkan ukuran besar kecilnya suatu perusahaan atau industri juga merupakan salah satu indikator keuangan yang sangat penting.

Aset atau aktiva adalah produk bernilai yang dikuasai atau dimiliki suatu perusahaan, baik berupa harta benda (properti), hak atau suatu tuntutan terhadap aset maupun jasa yang dimiliki. Aset dalam bisnis dan akuntansi merupakan sumber ekonomi yang dimiliki oleh seseorang individu atau sebuah bisnis atau perusahaan. Apapun properti atau barang berharga yang dimiliki, yang biasanya dianggap bisa berguna sebagai pembayaran utang seseorang, biasanya dianggap sebagai satu aset. Aset merupakan benda yang mudah diubah menjadi tunai.

Aset merupakan kunci sebuah perusahaan mencatat nilai keuangan aset yang dimiliki oleh sebuah perusahaan. Aset merupakan uang dan barang berharga lain milik individu atau bisnis. Aset atau liabilitas merupakan salah satu proses pemilihan investasi yang harus dilakukan secara seksama karena kesalahan dalam pemilihan bentuk investasi akan membawa dampak bank tidak bisa memenuhi kewajibannya kepada nasabah(Antonio, 2001).

\section{Konsep Deret Waktu (Time Series)}

Time series adalah suatu himpunan pengamatan yang dibangun secara berurutan dalam waktu. Waktu atau periode yang dibutuhkan untuk melakukan suatu peramalan itu biasanya disebut sebagai lead time yang bervariasi pada tiap persoalan.

Deret waktu adalah serangkaian pengamatan yang diambil berdasarkan urutan waktu dan antara pengamatan yang berdekatan saling berkorelasi, sehingga dikatakan bahwa pada deret waktu, tiap pengamatan yang diambil dari variabel berkorelasi dengan variabel itu sendiri pada waktu sebelumnya (Wei, 2006).

Di dalam meramal nilai suatu variabel di waktu yang akan datang harus diperhatikan dan dipelajari terlebih dahulu sifat dan perkembangan variabel itu di waktu yang lalu. Nilai dari suatu variabel dapat diramal jika sifat dari variabel tersebut diketahui di waktu sekarang dan di waktu yang lalu, untuk mempelajari bagaimana perkembangan historis dari suatu variabel, biasanya urutan nilai- nilai variabel itu diamati menurut waktu. Urutan waktu seperti ini dinamakan runtun waktu, dengan kata lain runtun waktu adalah serangkaian pengamatan terhadap suatu peristiwa, kejadian, gejala atau variabel yang diambil dari waktu ke waktu, dicatat secara teliti menurut urutan kejadiannya dan kemudian disusun sebagai data. Adapun waktu yang digunakan dapat berupa mingguan, bulan, tahun dan sebagainya. 
Makridakis et.al (Makridakis, Wheelwright, \& Mc. Gee, 1999) mengungkapkan bahwa langkah penting dalam memilih suatu metode runtun waktu (time series) yang tepat adalah dengan mempertimbangkan jenis pola data, sehingga metode yang paling tepat dengan pola data tersebut dapat diuji. Pola data dapat dibedakan menjadi empat, yaitu (1) pola horizontal, terjadi pada saat nilai data berfluktuasi di sekitar nilai rata- rata yang konstan, (2) pola musiman, terjadi bilamana suatu deret dipengaruhi oleh faktor musiman (misalnya kuartal tahun tertentu, bulanan, atau hari-hari pada minggu tertentu), (3) pola siklis, terjadi bilamana datanya dipengaruhi oleh fluktuasi ekonomi jangka panjang seperti yang berhubungan dengan siklus bisnis misalnya pada penjualan produk seperti mobil, baja dan lainnya, (4), pola trend, terjadi pada saat terdapat kenaikan atau penurunan sekuler jangka panjang dalam data.

\section{Konsep Forecasting}

Forecasting merupakan peramalan apa yang akan terjadi pada waktu yang akan datang, sedangkan rencana merupakan penentuan apa yang akan dilakukan pada waktu yang akan datang (Subagyo, 1986). Membuat rencana jangka panjang, suatu perusahaan harus mempertimbangkan kapasitas, elastisitas harga, forecast permintaan konsumen dan sebagainya.

Menurut Supranto (Supranto, 1984) forecasting adalah dugaan atau perkiraan mengenai terjadinya kejadian atau peristiwa pada waktu yang akan datang. Forecasting atau peramalan adalah memperkirakan sesuatu pada waktu- waktu yang akan datang berdasarkan data masa lampau yang dianalisis secara ilmiah, khususnya menggunakan metode statistika. Peramalan merupakan seni dan ilmu dalam memprediksikan kejadian yang mungkin dihadapi pada masa yang akan datang. Dengan digunakannya peralatan metode-metode peramalan maka akan memberikan hasil peramalan yang lebih dapat dipercaya ketetapannya.

Forecasting adalah ilmu memprediksi kondisi atau peristiwa yang akan terjadi dengan menggunakan data historis dan memproyeksikannya ke masa depan dengan beberapa bentuk model matematis. Peramalan menggunakan teknik-teknik peramalan yang bersifat formal maupun informal (Gaspersz, 1998). Kegiatan peramalan merupakan bagian integral dari pengambilan keputusan. Peramalan mengurangi ketergantungan pada hal-hal yang belum pasti (intuitif).

Dua hal pokok yang harus diperhatikan dalam proses peramalan yang akurat dan bermanfaat (Makridakis dkk., 1999): data yang relevan serta pemilihan teknik peramalan yang tepat. Untuk melakukan peramalan diperlukan metode tertentu dan metode mana yang digunakan tergantung dari data dan informasi yang akan diramal serta tujuan yang hendak dicapai.

Dalam prakteknya, terdapat berbagai metode peramalan kuantitatif. Pertama yaitu Moving Averages (rata-rata bergerak) baik 'simple' maupun 'weighted'. Kedua penghalusan eksponensial (exponential smoothing) yakni metode peramalan dengan menambahkan parameter alpha dalam modelnya untuk mengurangi faktor kerandoman.

Ketiga, proyeksi trend (trend projection). Metode proyeksi trend dengan regresi, merupakan metode yang digunakan baik untuk jangka pendek maupun jangka panjang. Metode 
ini merupakan garis trend untuk persamaan matematis. Selain yang disebutkan di atas, terdapat metode forecasting lain seperti: dekomposisi, ARIMA, dan metode forecasting lainnya.

Dalam kehidupan sosial segala sesuatu itu serba tidak pasti, sukar diperkirakan secara tetap. Hal ini perlu diadakan forecast, forecasting yang dibuat selalu diupayakan agar dapat: a. Meminimumkan pengaruh ketidakpastian terhadap perusahaan. b. Forecasting bertujuan mendapatkan ramalan (forecast) yang bisa meminimumkan kesalahan meramalkan (forecast error) yang biasanya di ukur dengan Mean Squared Error (MSE), Mean Absolute Error (MAE) dan lain sebagainya (Subagyo, 1986).

\section{Penelitian Terdahulu}

Studi Fadhli et al (Fadhli, Paramu, \& Nurhayati, 2014) mencoba menganalisis forecasting model yang sesuai untuk meramalkan harga saham perusahaan perbankan yang terpilih. Pemilihan model sangat penting dalam forecasting, karena model forecasting sangat berguna untuk dapat memperkirakan secara sistematis atas data yang relevan pada masa yang lalu. Penelitian ini menggunakan identifikasi pola data untuk menentukan metode forecasting yang akan digunakan.Cek pola data dilakukan dengan menggunakan autocorelation function. Jumlah sampel yang digunakan berjumlah 3 sampel, yaitu BNI, Mandiri, \& BRI. Hasil penelitian menunjukkan bahwa metode forecasting yang sesuai untuk meramalkan harga saham BNI dan Mandiri adalah metode ARIMA $(1,2,1)$. Sedangkan pada BRI metode forecasting yang sesuai adalah metode Exponential Smoothing Triple: Metode Kuadratik Satu Parameter dari Brown dengan nilai a $=0,3$.

Sementara riset Yuliani dan Kuswanto (Yuliani \& Kuswanto, 2010) berisi peramalan dengan menggunakan metode fungsi transfer meramalkan nilai dari suatu deret waktu (deret output) yang didasarkan pada nilai masa lalu dari deret itu sendiri dan juga didasarkan pula pada satu atau lebih deret waktu yang berhubungan dengan deret output tersebut (deret input $x_{t}$ ). Penelitian ini menggunakan metode fungsi transfer untuk meramalkan perkembangan aset perbankan syariah Indonesia sebagai variabel output yang diduga dipengaruhi oleh Dana Pihak Ketiga (DPK) dan total pembiayaan sebagai deret input. Model fungsi transfer terbaik dan nilai peramalan data aset untuk 12 bulan ke depan terhadap DPK dan pembiayaan telah didapatkan. Model tersebut menunjukkan bahwa metode fungsi transfer multi input memiliki MSE yang lebih kecil daripada metode ARIMA. Nilai peramalan selama Januari hingga Desember 2011 berkisar pada Rp 85 Triliun hingga Rp 102 Triliun.

Hendriana (Hendriana, 2011) menyatakan bahwa hasil dari model ARIMA yang dipilih yaitu memberikan informasi bahwa pertumbuhan bank syariah di Indonesia mengalami fluktuasi, tetapi bila dilihat dari hasil peramalan nominal di tiap triwulannya terjadi peningkatan. Kondisi ini ditunjukkan dari variabel yang digunakan dalam penelitian ini yaitu aset, DPK, pembiayaan dan laba tahun berjalan. Nilai nominal dari aset, DPK, pembiayaan dan laba tahun berjalan diprediksi mengalami kenaikan untuk tahun 2011 dan 2012. Tingkat pertumbuhan dari keempat variabel yang diteliti mengalami fluktuasi pada triwulan I atau Maret tahun 2011 sampai dengan triwulan IV atau Desember tahun 2012. 
Riset Wulansari dan Suhartono (Wulansari \& Suhartono, 2014) bertujuan untuk meramalkan netflow uang kartal dengan metode ARIMAX dan Artificial Neural Network (ANN) dilanjutkan dengan membandingkan hasil ketepatan peramalan kedua metode tersebut. Pada penelitian ini netflow uang kartal akan diramalkan dengan ARIMAX dengan efek variasi kalender dan variabel prediktor IHK serta kurs. Metode yang digunakan untuk ANN adalah metode Radial Basis Function Network (RBFN). Diperoleh hasil bahwa model ARIMAX dengan efek variasi kalender dan variabel prediktor IHK merupakan model dengan peramalan netflow uang kartal terbaik.

Ma'rufah et.al (Ma'rufah, Santi Puteri, \& Suhartono, 2013), dalam penelitian ini, variabel yang digunakan adalah biaya dana dan LDR sebagai variabel bebas serta pendapatan bunga bank sebagai variabel tak bebas. Penelitian ini menggunakan pendekatan metode fungsi transfer dan neural network untuk meramalkan pendapatan bunga bank. Hasil yang diperoleh menunjukkan dengan menggunakan pendekatan fungsi transfer kedua variabel bebas berkaitan secara signifikan dengan pendapatan bunga BRI sedangkan untuk BCA hanya variabel biaya dana yang berkaitan secara signifikan terhadap pendapatan bunga. Selain itu, berdasarkan ketepatan peramalan metode fungsi transfer merupakan metode yang paling sesuai untuk meramalkan pendapatan bunga BRI sedangkan metode neural network merupakan metode yang sesuai untuk meramalkan pendapatan bunga BCA.

\section{METODE}

\section{Metode Peramalan Kuantitatif}

Rancangan Penelitian ini adalah tentang forecasting model. Data yang digunakan dalam penelitian ini merupakan data sekunder yang berupa data time series total aset perbankan syariah Indonesia selama tahun 2002 hingga 2019 bulan Juli. Yang termasuk di dalam objek penelitian adalah total aset Bank Umum Syariah (BUS) dan Unit Usaha Syariah (UUS). Data sekunder diperoleh dari laporan statistik perbankan syariah (SPS) Otoritas Jasa Keuangan. Alat analisis yang digunakan adalah software QMv3 (Quantitative Method).

Metode peramalan kuantitatif dapat dibagi menjadi dua tipe, causal dan time series. Metode peramalan causal meliputi faktor-faktor yang berhubungan dengan variabel yang diprediksi seperti analisis regresi. Peramalan time series merupakan metode kuantitatif untuk menganalisis data masa lampau yang telah dikumpulkan secara teratur menggunakan teknik yang tepat. Hasilnya dapat dijadikan acuan untuk peramalan nilai di masa yang akan datang (Makridakis dkk., 1999).

Metode Peramalan Kuantitatif untuk meramalkan suatu keadaan dengan menggunakan data historis tanpa menghiraukan pengaruh atau hubungan dengan variabel lainnya, metode peramalan yang biasa digunakan adalah metode kuantitatif statistik yaitu dengan melihat pola perubahan data dari waktu ke waktu (Makridakis \& Wheelwright, 2010). Peramalan kuantitatif juga dapat diterapkan bila terdapat tiga kondisi berikut: (Martiningtyas, 2004) 1. Tersedia informasi tentang masa lalu. 2. Informasi tersebut dapat dikuantitatifkan dalam bentuk data numerik. 3. Dapat diasumsikan bahwa beberapa aspek pola masa lalu terus berlanjut di masa 
mendatang. Beberapa metode peramalan kuantitatif statistik: (Makridakis \& Wheelwright, 2010). 1. Metode Moving Averages (rata-rata bergerak) Peramalan dilakukan dengan mengambil sekelompok nilai pengamatan, mencari rata-ratanya, lalu menggunakan rata-rata tersebut sebagai ramalan untuk periode berikutnya. Metode ini meliputi Single Moving Average dan Double Moving Average. 2. Metode Exponential Smoothing yang juga meliputi metode Single Exponential Smoothing, Double Exponential Smoothing dan Triple Exponential Smoothing 3. Metode Dekomposisi Metode dekomposisi didasarkan pada hal yang telah terjadi akan berulang kembali dengan pola yang sama. Metode dekomposisi mempunyai 4 (empat) komponen utama pola perubahan, yaitu Trend (T), Fluktuasi Musiman (M), Fluktuasi Siklik (S), dan perubahan yang bersifat Random (R). a. Trend, Trend adalah rata-rata perubahan dalam jangka panjang. Faktor trend menggambarkan perilaku data yang meningkat, menurun atau tidak berubah. Adapun persamaan trend adalah: (Makridakis \& Wheelwright, 2010).

\section{Decomposition multiplicative}

Salah satu cara analisis terhadap data time-series adalah melakukan dekomposisi untuk tujuan mengidentifikasi komponen-komponen yang mempengaruhi data. Empat komponen time-series yang lazim dipelajari adalah 1. Tren, 2. Siklis, 3. Musiman, 4. Stationari/Horisontal. Dalam dekomposisi, model matematis dari sebuah time series jangka panjang (tahunan) dapat dianggap sebagai hasil perkalian dari komponen fluktuasi trend dan fluktuasi siklis.

$$
X=T x C
$$

Di mana:

$\mathrm{X}$ adalah nilai aktual

$\mathrm{T}$ adalah fluktuasi tren

$\mathrm{C}$ adalah indeks fluktuasi siklis

Sedangkan untuk data time series jangka pendek (kurang dari 1 tahun), model matematis merupakan produk dari keempat komponen:

$$
X=T C S H
$$

S adalah fluktuasi seasonal (musiman)

$\mathrm{H}$ adalah fluktuasi horizontal (stationari)

Analisa decomposition digunakan untuk menganalisa data yang terdapat pola musiman serta menghasilkan peramalan dengan periode ke depan yang panjang. Analisa ini memiliki 2 model yaitu:

- 1. Additive

- 2. Multiplicative.

Model Additive digunakan untuk ukuran pola seasonal tidak proporsional dengan data (tidak ada pola melebar atau mengecil tapi konstan) dan garis lurus dengan menambah bentuk 
musiman, sedangkan model Multiplicative ukuran pola musiman proporsional dengan data (terdapat pola melebar atau mengecil).

Dekomposisi Aditif menghitung dekomposisi time seris pada komponen-komponen trend, musiman, siklus dan error. Metode ini mengidentifikasi ramalan masa depan dan menjumlahkan proyeksi yang hasil peramalan. Model diasumsikan bersifat aditif (semua komponen ditambahkan untuk mendapatkan hasil peramalan). Persamaan model ini adalah:

$$
X^{\prime}{ }_{t}=T_{t}+S_{t}+C_{t}+\varepsilon_{t}
$$

Di mana T adalah trend, $\mathrm{S}$ adalah komponen musiman, $\mathrm{C}$ adalah komponen siklik/siklis dan $\varepsilon$ adalah error.

Dekomposisi multiplikatif menghitung dekomposisi time series pada komponenkomponen trend, musiman, siklus, dan error dan kemudian memprediksi nilai masa depan. Model diasumsikan bersifat multiplikatif (semua komponen dikalikan satu sama lain untuk mendapatkan model peramalan). Persamaan model ini adalah:

$$
X_{t}^{\prime}=T_{t} * S_{t} * C_{t} * \varepsilon_{t}
$$

Di mana T adalah trend, $\mathrm{S}$ adalah komponen musiman, $\mathrm{C}$ adalah komponen siklik/siklis dan $\varepsilon$ adalah error.

\section{Exponential Smoothing with Trend}

Adalah jenis lain dari exponential smoothing yang digunakan ketika sebuah deret waktu menunjukkan sebuah tren linier. Rumus penghalusan eksponensial dengan penyesuaian tren menurut Heizer dan Render (Heizer \& Render, 2009) adalah:

$$
\begin{gathered}
F I T_{t}=\mathrm{F}_{\mathrm{t}}+\mathrm{T}_{\mathrm{t}} \\
F_{t}=\alpha\left(A_{t-1}\right)+(1-\alpha)\left(\mathrm{F}_{\mathrm{t}-1}+\mathrm{T}_{\mathrm{t}-1}\right) \\
T_{t}=\beta\left(F_{t}-F_{t-1}\right)+(1-\beta) T_{t-1}
\end{gathered}
$$

Keterangan:

$\mathrm{Ft}=$ peramalan dengan eksponensial yang dihaluskan dari data berseri pada periode $\mathrm{t}$,

$\mathrm{Tt}=$ tren dengan eksponensial yang dihaluskan pada periode $\mathrm{t}$,

At $=$ permintaan aktual pada periode $t$,

a $=$ konstanta penghalusan untuk rata-rata $(0 \leq \alpha \leq 1)$,

$\beta=$ konstanta penghalusan untuk tren $(0 \leq \beta \leq 1)$.

\section{Trend Analysis (Regress over time)}

Adalah suatu metode peramalan serangkaian waktu yang sesuai dengan garis tren terhadap serangkaian titik-titik data masa lalu, kemudian diproyeksikan ke dalam peramalan masa depan. Rumus analisis tren menurut Heizer dan Render (Heizer \& Render, 2009) adalah: 


$$
\begin{gathered}
(y=a+b x) \\
a=\frac{\sum y}{n} \\
b=\frac{\sum x y}{x^{2}}
\end{gathered}
$$

Keterangan:

$\mathrm{Y}=$ Variabel Terikat

$\mathrm{X}=$ Variabel Bebas (waktu)

$\mathrm{a}=$ Konstanta

$\mathrm{b}=$ Koefisien Tren

$\mathrm{n}=$ Jumlah data (pengamatan)

\section{HASIL DAN PEMBAHASAN}

Seperti yang telah disampaikan dalam bagian sebelumnya, forecasting adalah ilmu memprediksi kondisi atau peristiwa yang akan terjadi dengan menggunakan data historis dan memproyeksikannya ke masa depan dengan beberapa bentuk model matematis. Peramalan menggunakan teknik-teknik peramalan yang bersifat formal maupun informal (Makridakis dkk., 1999)(Gaspersz, 1998). Kegiatan peramalan merupakan bagian integral dari pengambilan keputusan. Peramalan mengurangi ketergantungan pada hal-hal yang belum pasti (intuitif).

Dua hal pokok yang harus diperhatikan dalam proses peramalan yang akurat dan bermanfaat (Makridakis dkk., 1999): data yang relevan serta pemilihan teknik peramalan yang tepat. Untuk melakukan peramalan diperlukan metode tertentu dan metode mana yang digunakan tergantung dari data dan informasi yang akan diramal serta tujuan yang hendak dicapai.

Dalam prakteknya, terdapat berbagai metode peramalan kuantitatif. Pertama yaitu Moving Averages (rata-rata bergerak) baik 'simple' maupun 'weighted'. Kedua penghalusan eksponensial (exponential smoothing) yakni metode peramalan dengan menambahkan parameter alpha dalam modelnya untuk mengurangi faktor kerandoman. Tiga, proyeksi trend (trend projection). Metode proyeksi trend dengan regresi, merupakan metode yang digunakan baik untuk jangka pendek maupun jangka panjang. Metode ini merupakan garis trend untuk persamaan matematis. Selain yang disebutkan di atas, terdapat metode forecasting lain seperti: dekomposisi, ARIMA, dan lain-lain.

Tujuan penelitian ini mencoba melakukan prediksi total aset yang akan dicapai industri perbankan syariah di Indonesia pada akhir tahun 2020. Termasuk di dalam objek penelitian adalah total aset Bank Umum Syariah (BUS) dan Unit Usaha Syariah (UUS). Alat bantu yang digunakan adalah software QMv3 (Quantitative Method) dengan data time series tahunan mulai 2002 hingga 2018. Berdasarkan hasil pengolahan data yang telah dilakukan, hasil perhitungan 
prediksi pangsa pasar total Industri perbankan syariah di Indonesia untuk masa yang akan datang adalah sebagai terlampir dalam tabel berikut ini.

Tabel 4.1. Hasil Prediksi Industri Perbankan Syariah Indonesia (Rp Triliun)

\begin{tabular}{|c|c|c|c|}
\hline & $\begin{array}{c}\text { Trend } \\
\text { Analysis }\end{array}$ & $\begin{array}{c}\text { Multiplicative } \\
\text { Decomposition }\end{array}$ & $\begin{array}{c}\text { Exponential } \\
\text { Smoothing }\end{array}$ \\
\hline $\mathbf{2 0 0 2}$ & 4 & 4 & 4 \\
\hline $\mathbf{2 0 0 3}$ & 8 & 8 & 8 \\
\hline $\mathbf{2 0 0 4}$ & 15 & 15 & 15 \\
\hline $\mathbf{2 0 0 5}$ & 21 & 21 & 21 \\
\hline $\mathbf{2 0 0 6}$ & 27 & 27 & 27 \\
\hline $\mathbf{2 0 0 7}$ & 37 & 37 & 37 \\
\hline $\mathbf{2 0 0 8}$ & 50 & 50 & 50 \\
\hline $\mathbf{2 0 0 9}$ & 66 & 66 & 66 \\
\hline $\mathbf{2 0 1 0}$ & 98 & 98 & 98 \\
\hline $\mathbf{2 0 1 1}$ & 145 & 145 & 145 \\
\hline $\mathbf{2 0 1 2}$ & 195 & 195 & 195 \\
\hline $\mathbf{2 0 1 3}$ & 242 & 242 & 242 \\
\hline $\mathbf{2 0 1 4}$ & 272 & 272 & 272 \\
\hline $\mathbf{2 0 1 5}$ & 296 & 296 & 296 \\
\hline $\mathbf{2 0 1 6}$ & 356 & 356 & 356 \\
\hline $\mathbf{2 0 1 7}$ & 424 & 424 & 424 \\
\hline $\mathbf{2 0 1 8}$ & 477 & 477 & 477 \\
\hline $\mathbf{2 0 1 9} *$ & 481 & 481 & 481 \\
\hline $\mathbf{2 0 2 0} *$ & 516.09 & 523.72 & 553 \\
\hline $\mathbf{2 0 2 1} *$ & 545.7 & 583.8 & \\
\hline $\mathbf{M A P E}$ & 0.07 & 0.07 & 0.03 \\
\hline
\end{tabular}

*Hasil prediksi; **Data hingga Juli 2019

Berdasarkan tabel 4.1, secara umum pangsa pasar Industri perbankan syariah di Indonesia mulai tahun 2002 hingga tahun 2018 mengalami kenaikan yang cukup signifikan. Jika pada tahun 2002 nilainya hanya 4 triliun rupiah, pangsa pasar Industri perbankan syariah di Indonesia pada tahun 2018 meningkat menjadi 477 triliun rupiah.

Hasil perhitungan prediksi pangsa pasar industri perbankan Syariah di Indonesia untuk pendekatan analisis trend pada tahun 2020 diperkirakan mencapai Rp 516,09 triliun. Berikut ini adalah grafik metode trend analysis (regress over time) untuk pangsa pasar Industri perbankan syariah di Indonesia dimana garis hitam adalah data riil dan garis putus-putus biru adalah data prediksi. 


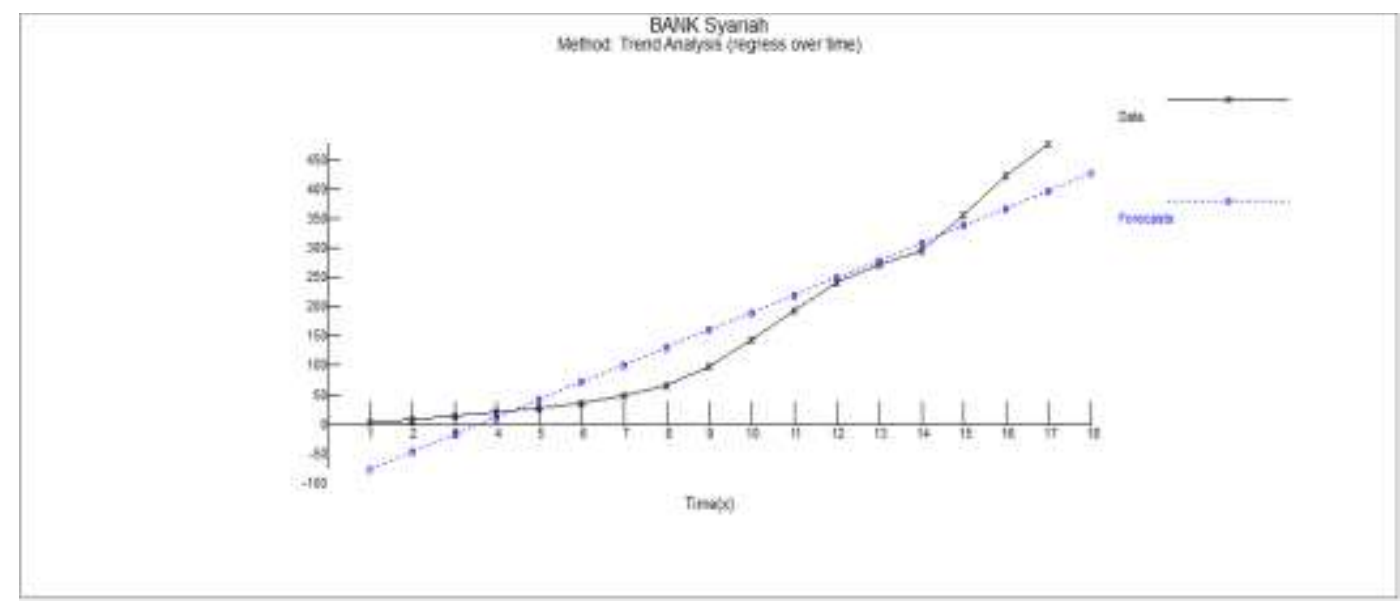

Grafik 4.1. Metode Trend Analysis

Sementara itu, hasil perhitungan prediksi pangsa pasar industri Bank Syariah di Indonesia dengan pendekatan dekomposisi (Multiplicative Decomposition) diperkirakan mencapai Rp 523,72 triliun di akhir 2020. Berikut ini adalah grafik metode dekomposisi untuk pangsa pasar Industri perbankan syariah di Indonesia dimana garis hitam adalah data riil dan garis putus-putus biru adalah data prediksi.

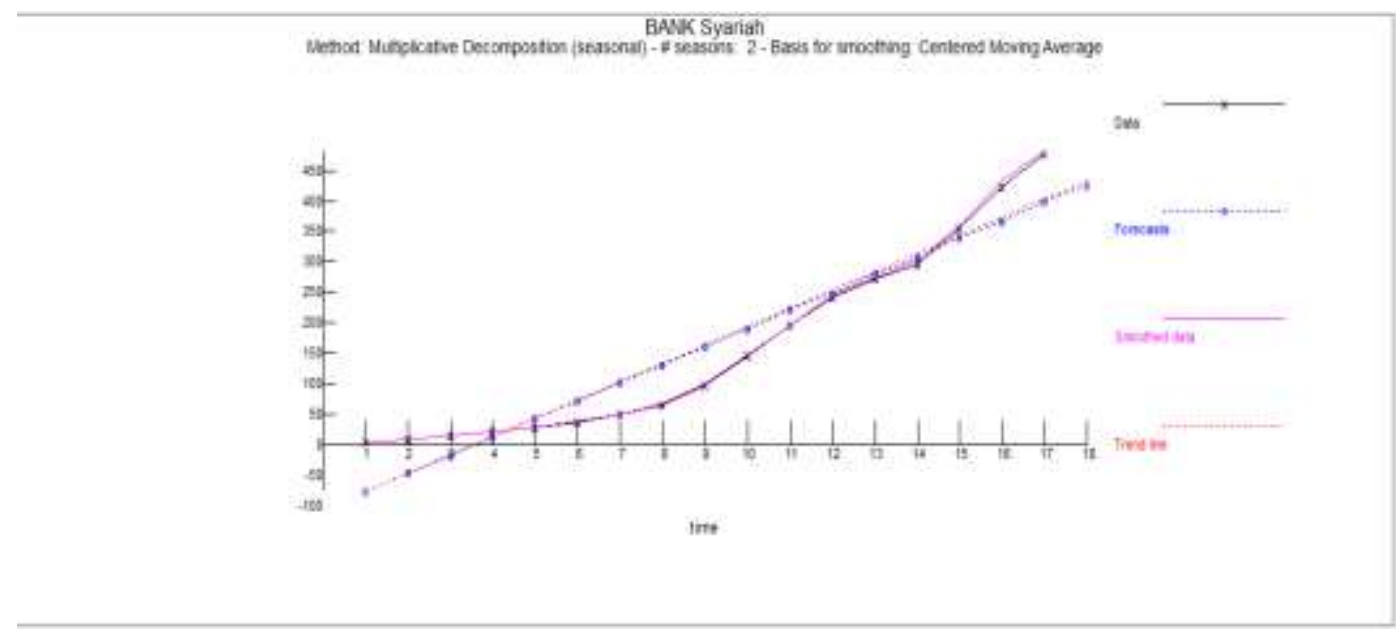

\section{Grafik 4.2. Metode Multiplicative Decomposition}

Terakhir adalah hasil pengukuran metode Exponential Smoothing with trend. hasil perhitungan prediksi pangsa pasar industri Bank Syariah di Indonesia dengan pendekatan ini diperkirakan mencapai Rp 553 triliun di akhir 2020. Berikut ini adalah grafik metode exponential smoothing untuk pangsa pasar Industri perbankan syariah di Indonesia dimana garis hitam adalah data riil dan garis putus-putus biru adalah data prediksi. 


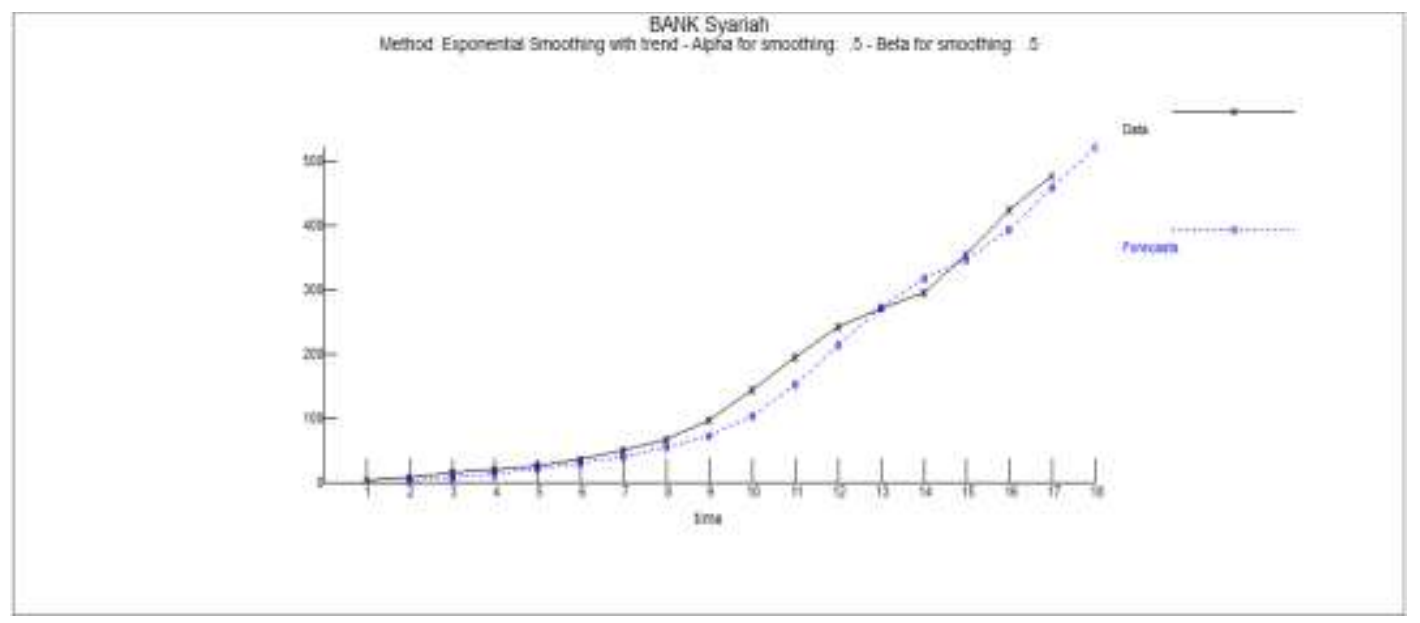

Grafik 4.3. Metode Exponential Smoothing with Trend

Nilai MAPE (Mean Absolute Percent Error) atau nilai persentase error rata-rata untuk ketiga metode di atas adalah 0.07 untuk Trend Analysis dan metode Multiplicative Decomposition, serta 0.03 untuk metode Exponential Smoothing with Trend. Artinya, metode ketiga relatif lebih baik dalam memprediksi dibandingkan dengan metode lainya (Exponential Smoothing with trend).

Maka, jika tidak ada hal luar biasa yang terjadi -yang sifatnya unorganik- dan asumsi 'ceteris paribus', aset bank syariah di Indonesia pada akhir tahun 2020 akan berada pada kisaran Rp 516 hingga Rp 553 triliun 'saja'. Range nilai ini juga menunjukkan skema pesimis-optimis. Jika kita melakukan penghitungan perbandingan antara posisi total aset bank syariah saat akhir data pada Statistik Perbankan Syariah OJK tahun 2019 bulan Juli lalu yakni Rp 481 triliun dengan prediksi akhir 2020 nanti, untuk skema pesimis, akan didapatkan angka pertumbuhan sekitar 7,3\%. Untuk skema prediksi moderat, akan didapatkan angka pertumbuhan sekitar 8,7\%. Sementara itu untuk skema prediksi optimis, prediksi total aset bank syariah di Indonesia akan didapatkan angka pertumbuhan sekitar 14,9\%.

Realitas yang terjadi pada industri perbankan syariah di Indonesia, non performing financial (NPF) BUS mulai memburuk di tahun 2015, sehingga dua tahun berikutnya 20162017 secara umum merupakan pembenahan untuk memulihkan NPF, yang sebelumnya membuat kinerja BUS menurun. Tingginya nilai NPF yang berakibat pada penurunan kinerja BUS di periode 2015 adalah karena adanya pelemahan di sektor investasi pertambangan dan perdagangan umum, sehingga berimbas pada anjloknya return on Asset (ROA) BUS.

Sementara untuk Unit Usaha Syariah (UUS), relatif lebih memperlihatkan kinerja yang stabil, meskipun pada sisi pembiayaan pada perdagangan umum juga sedikit terpengaruh oleh pelambatan ekonomi nasional pada periode 2014 sampai dengan 2017. Terdapat pelambatan pembiayaan sehingga pembagi non performing financing (NPF) menjadi lebih kecil dan NPF menjadi besar. Turunnya pangsa pasar terjadi seiring kondisi ekonomi yang juga melemah. Pelambatan ini juga terjadi di industri keuangan konvensional, meski memang terlihat lebih tajam pada industri perbankan syariah. 
Ada beberapa faktor yang menjadi penghambat berkembangnya industri perbankan syariah di Indonesia, yaitu: 1) Belum memadainya permodalan Bank Syariah; 2) Lemahnya pemahaman praktisi bank syariah; 3) Kurangnya dukungan pemerintah dan 4) Trust \& minat masyarakat terhadap bank syariah cenderung rendah (Rusydiana, 2016). Oleh karenanya pihak terkait perlu perbaikan dari sisi permodalan, peningkatan kualitas SDM bank syariah, dan tidak kalah penting adalah support pemerintah.

Dari sisi opportunities, menurut Siswanto (2005), terdapat 5 faktor yang dapat mendukung pengembangan sistem ekonomi dan keuangan syariah di Indonesia, termasuk di dalamnya perbankan syariah. Pertama, fatwa bahwa bunga bank adalah riba dan haram. Kedua, tren kesadaran masyarakat Muslim yang semakin meningkat, khususnya pada masyarakat kelas menengah ke atas. Ketiga, sistem ekonomi syariah berhasil menunjukkan keunggulannya, teruji pada saat terjadi krisis ekonomi. Ketika bank-bank konvensional tumbang dan butuh suntikan dana pemerintah hingga ratusan triliun, Bank Muamalat Indonesia, sebagai bank syariah pertama di Indonesia, mampu melewati krisis dengan selamat tanpa bantuan dana pemerintah sepeserpun. Keempat, UU Perbankan Syariah yang kini terus digodok, akan menjadi payung hukum bagi perbankan syariah di Indonesia. Kelima, tuntutan integrasi Lembaga Keuangan Syariah (LKS) yang saling menopang. Seperti contoh Bank syariah dapat menggunakan asuransi syariah untuk menutup resiko pembiayaan terhadap nasabahnya. Sebaliknya, asuransi syariah dapat menyimpan dananya di bank syariah, pasar modal syariah, maupun reksadana syariah (Ascarya, Yumanita, \& Anwar, 2006).

Forecasting adalah ilmu memprediksi kondisi atau peristiwa yang akan terjadi dengan menggunakan data historis dan memproyeksikannya ke masa depan dengan beberapa bentuk model matematis. Dalam penelitian ini penulis mencoba melakukan prediksi seberapa besar total aset yang akan dicapai khususnya pada lembaga perbankan syariah di Indonesia pada akhir tahun 2020. Termasuk di dalam objek penelitian adalah total aset Bank Umum Syariah (BUS) dan Unit Usaha Syariah (UUS).

Hasilnya menunjukkan bahwa dengan metode dekomposisi (Multiplicative Decomposition), aset bank syariah Indonesia diperkirakan mencapai Rp 523,72 triliun di akhir 2020. Sedikit berbeda dengan hasil tersebut, dengan metode analisis tren, aset bank syariah Indonesia diperkirakan mencapai Rp 516,09 triliun. Adapun jika menggunakan pendekatan exponential smoothing dengan tren pada akhir 2020 aset bank syariah Indonesia diperkirakan mencapai Rp 553 triliun. Maka, jika tidak ada hal luar biasa yang terjadi -yang sifatnya unorganik- dan asumsi 'ceteris paribus', aset bank syariah di Indonesia pada akhir tahun 2020 akan berada pada kisaran Rp 516 hingga Rp 553 triliun 'saja'. Range nilai ini juga menunjukkan skema pesimis-optimis.

Untuk skema pesimis, akan didapatkan angka prediksi pertumbuhan total aset bank syariah sekitar 7,3\%. Sementara itu untuk skema prediksi moderat dan optimis, prediksi total aset bank syariah di Indonesia akan didapatkan angka pertumbuhan sekitar 8,7\% dan 14,9\%. Agar mencapai target pertumbuhan yang diharapkan, industri perbankan syariah di Indonesia 
perlu perbaikan dari sisi permodalan, peningkatan kualitas SDM bank syariah, dan tidak kalah penting adalah support pemerintah.

\section{REFERENSI}

Adawiyah, Nida Nusaibatul Dan Subaweh, Imam. 2013. Analisis Pengaruh Pemahaman Ekonomi Syariah Terhadap Kolektabilitas Pada Nasabah Lembaga Keuangan Syariah di Wilayah Depok. Jakarta: Jurusan Akuntansi, Fakultas Ekonomi Universitas Gunadarma.

Almilia, Luciana Spica dan Herdinigtyas Winny. 2005. "Analisis Rasio CAMEL Terhadap Prediksi Kondisi Bermasalah Pada Lembaga Perbankan Periode 2000-2002”. Jurnal Akuntansi \& Keuangan, Vol. 7, No. 2.

Antonio, S. 2001. Bank Syariah dari Teori ke Praktek. Jakarta: Gema Insani.

Ascarya, Yumanita, Diana, dan Anwar Enny. 2006. Sinergi Sistem Keuangan Konvensional dan Sistem Keuangan Islam. Occasional Paper, Pusat Pendidikan dan Studi Kebanksentralan - Bank Indonesia.

Ascarya. 2007. Sistem Keuangan dan Moneter Islam. Pusat Pendidikan dan Studi Kebanksentralan Bank Indonesia. Bank Indonesia.

Deperindag. 2002. Rencana Induk Pengembangan Industri Kecil Menengah 2002-2004. Departemen Perindustrian dan Perdagangan, Jakarta.

Fadhli, Rizki Maulana, Paramu, Hadi dan Nurhayati. 2014. Forecasting Model Berbasis Data Time Series Pada Harga Saham Perusahaan Perbankan Yang Terpilih. Jember: Jurusan Manajemen, Fakultas Ekonomi, Universitas Jember.

Heizer, J \& Render, B. 2009. Manajemen Operasi (edisi 9). Jakarta: Penerbit Salemba Empat. Alih bahasa oleh Sungkono, C.

Hendriana, Nadia Galuh. 2011. Analisis Perkembangan dan Prediksi Tingkat Pertumbuhan Bank Syariah di Indonesia. Jakarta: Jurusan Manajemen, Fakultas Ekonomi dan Bisnis Universitas Islam Negeri Syarif Hidayatullah.

Latianingsih, Nining dan Ninggarwati SEL. 2010. "Kontrak Standar Pada Lembaga Keuangan Syariah BMT Dalam Perspektif Perlindungan Konsumen”. Jurnal Ilmiah Orasi Bisnis Edisi ke- 4.

Lubis, Abdul Fattah. 2008. Analisa Pertumbuhan Bisnis Bank Syariah (Studi Kasus PT Bank Muammalah, Tbk). Jakarta: Fakultas Ekonomi, Universitas Islam Negeri Syarif Hidayatullah. 
Ma'rufah, Nayla, Rahayu Santi Puteri, Suhartono. 2013. "Peramalan Pendapatan Operasional Bank Menggunakan Metode Fungsi Transfer dan Neural Network”. Jurnal Sains dan Seni Pomits Vol. 2, No. 2.

Makridakis, Spyros. Steven C. Wheelwright, dan Victor E. McGee. 1999. Metode dan Aplikasi Peramalan. Edisi Kedua. Jakarta: Erlangga.

Makridakis dan Wheelwright, Steven. 2010. Metode dan Aplikasi Peramalan, Jilid1. Tangerang: Binarupa Aksara Publisher.

Martiningtyas, Nining. 2004. Buku Materi Kuliah STIKOM Statistika, STIKOM.

Muhammad. 2002. Managemen bank syariah. Yogyakarta: UPP AMP YKPN.

Nurfalah, I., Rusydiana, A.S., Laila, N., and Cahyono, E.F. (2018), "Early warning to banking crises in the dual financial system in Indonesia: The markov switching approach", JKAU: Islamic Economics, Vol.31, No.2, pp.133-156.

Otoritas Jasa Keuangan. 2013. Laporan Perkembangan Keuangan Syariah 2013.

Otoritas Jasa Keuangan. 2017. Laporan Statistik Perbankan Syariah dan Sukuk Korporasi 20052017.

Pratiwhi, Y. 2008. Faktor-faktor yang mempengaruhi pertumbuhan proporsi aset perbankan syariah di Indonesia. Jakarta: Program pascasarjana, Universitas Inonesia.

Rani, L., Rusydiana, A., and Widiastuti, T. (2017). "Comparative analysis of Islamic bank's productivity and conventional bank's in Indonesia period 2008-2016". In 1 st International Conference on Islamic Economics, Business and Philanthropy (ICIEBP 2017), pp. 118123.

Rusydiana, Aam S. 2018. "Indeks malmquist untuk pengukuran efisiensi dan produktivitas bank syariah di Indonesia", Jurnal Ekonomi dan Pembangunan LIPI, Vol.26, No.1, pp.47-58.

Rusydiana, Aam S., and Yulizar D. Sanrego, 2018. "Mesuring the performance of Islamic banking in Indonesia: An application of Maslahah efficiency quadrant (MEQ)". Journal of Monetary Economics and Finance, Vol 3 Special Issue, pp.103-130.

Rusydiana, Aam S., and Irman Firmansyah, 2017. "Efficiency versus Maqasid sharia index: An application on Indonesia Islamic bank". Shirkah Journal of Economics and Business, Vol 2 No 2, 2017.

Rusydiana, Aam S. 2016. "Analisis masalah pengembangan perbankan syariah di Indonesia: Aplikasi metode analytic network process". Esensi: Jurnal Bisnis dan Manajemen, Vol. 6, No. 2, pp.237-246.

Subagyo, Pangestu. 1986. Foreasting Konsep dan Aplikasi. Yogyakarta: BPFE. 
Supranto, J. 1984. Metode Kuantitatif untuk Perencanaan.Jakarta: Erlangga.

Ulfah, M. 2009. Analisa Perkembangan Aset, Dana Pihak Ketiga (DPK), dan Pembiayaan Perbankan Syariah di Indonesia. Jakarta: Program Sarjana, Universitas Gunadarma.

Wei, W. S. 2006. Time Series Analysis Univariate and Multivariate Methods. New York: Philadelphia: Pearson.

Wulansari, Renny Elfira dan Suhartono. 2014. "Peramalan Netflow Uang Kartal dengan Metode ARIMAX dan Radial Basis Function Network (Studi Kasus Di Bank Indonesia)". Jurnal Sains dan Seni Pomits Vol. 3, No.2.

Yuliani, Faridah dan Kuswanto, Heri. 2010. Peramalan Aset dengan Memperhatikan Dana Pihak Ketiga (DPK) dan Pembiayaan Perbankan Syariah di Indonesia dengan Metode Fungsi Transfer. Surabaya: Jurusan Statistika Institut Teknologi Sepuluh Nopember. 